\title{
Recovery Kitin Dari Limbah Cangkang Rajungan
}

\author{
Muhammad Hazqil Kadzim ${ }^{1}$, Djaenudin ${ }^{2}$, Etih Hartati ${ }^{3}$ \\ ${ }^{1,3}$ Teknik Lingkungan, Fakultas Teknik Sipil dan Perencanaan, Institut Teknologi Nasional (Itenas), Bandung \\ ${ }^{2}$ Loka Penelitian Teknologi Bersih, Lembaga Ilmu Pengetahuan Indonesia \\ *Koresponden email: hazqilmuhammad@ mhs.itenas.ac.id
}

Diterima: 21 September 2020

Disetujui: 3 Oktober 2020

\begin{abstract}
The small crab animal is important for the fisheries sector in Indonesia, but usually the small crab industry only takes meat and allows the crab shell to become a pile of waste. To reduce the potential for pollution caused by a small crab shell waste, the waste can be reused to obtain chitin. Small crab shell waste still contains quite a lot of chemical compounds, including protein, minerals (CACO), and chitin. The study conducted chitin extraction with a process preceded by deproteination and then demineralization. Chitin was characterized using Fourier Transform Infra Red (FTIR) and Scanning Electron Microscopy (SEM). The results showed that chitin was successfully extracted from the small crab shell through the deproteination and demineralization process with FTIR 1, which results the characteristic spectrum of chitin compounds such as waves of $3433 \mathrm{~cm}$ 'for $-\mathrm{OH}$, -NH groups. The absorption around the wave number $3433 \mathrm{~cm}$ occurs because of the overlap between the absorption -NH and $-\mathrm{OH}$ and the wave number $701 \mathrm{~cm}$ 'for the b-1,4-glycosidic group.
\end{abstract}

Keywords: chitin, FITR, crab, deacetylation, deproteination

\begin{abstract}
Abstrak
Hewan rajungan merupakan hal yang penting bagi sektor perikanan di Negara Indonesia, akan tetapi hewan rajungan lebih banyak digunakan bagian dagingnya saja sedangkan bagian lainnya (cangkang) akan menjadi limbah. Untuk mengurangi potensi pencemaran yang disebabkan oleh limbah cangkang rajungan, limbah tersebut dapat dimanfaatkan kembali untuk dapatkan kitin. Cangkang rajungan yang telah menjadi limbah tidak hanya terdapat kandungan kitin saja akan tetapi masih terdapat kandungan lain seperti protein dan mineral $\left(\mathrm{CaCO}_{3}\right)$. Penelitian melakukan ekstraksi kitin dengan didahului proses deproteinasi lalu dilanjutkan dengan demineralisasi. Fourier Transform Infra Red (FTIR) dan Scanning Electron Microscopy (SEM) akan digunakan untuk karakterisasi kitin. Hasil penelitian didapatkan kitin berhasil diekstraksi dari limbah cangkang rajungan melalui proses deproteinasi dan demineralisasi dengan ditandai hasil FTIR memperlihatkan spektrum ciri khas senyawa kitin seperti pada gelombang $3433 \mathrm{~cm}^{-1}$ untuk gugus - $\mathrm{OH}$, -NH dan juga terdapat bilangan gelombang $701 \mathrm{~cm}^{-1}$ untuk gugus $\beta$-1,4-glikosidik.
\end{abstract}

Kata Kunci: Kitin, FITR, rajungan, deasetilasi, deproteinasi

\section{Pendahuluan}

Negara Indonesia memiliki luas lautan sebesar 3,25 juta $\mathrm{km}^{2}$ [1] sehingga sering disebut sebagai negara maritim. Salah satu potensi yang luar biasa yang dimiliki lautan Indonesia adalah kitin yang dihasilkan dari hewan berjenis (crustacea) atau hewan invertebrate laut berkulit keras salah satunya adalah rajungan. Rajungan salah satu hewan yang memberikan dampak positif dalam bidang ekonomi dan hal yang penting di Indonesia terutama dalam bidang perikanan. Industri yang mengolah hewan rajungan biasanya memanfaatkan bagian dalam cangkang (daging) hewan rajungan serta membuang bagian lainnya (cangkang). Bagian cangkang yang dibuang terdiri dari bagian kulit dan kepala, dimana bagian tersebut akan menjadi limbah. Limbah rajungan masih belum dimanfaatkan dengan baik, bahkan pencemaran lingkungan dapat terjadi akibat buangan yang cukup besar dari cangkang rajungan [2].

Potensi pencemaran lingkungan dapat dikurangi dengan pemanfaatan limbah cangkang rajungan dan pemanfaatan limbah dapat memberikan nilai tambah yang positif. Kandungan yang terdapat di dalam cangkang rajungan yang telah menjadi limbah masih bermanfaat diantaranya yaitu $30-40 \%$ kandungan protein, 30-50\% kandungan mineral, dan 20-30\% kandungan kitin [3]. Kandungan dalam cangkang rajungan yang sangat besar potensinya untuk dimanfaatkan adalah kitin. Kitin secara biologis mudah terdegradasi, tidak bersifat beracun dan tidak dapat larut di dalam air [4]. Kegunaan kandungan kitin sangatlah luas seperti sebagai penyerap bahan limbah logam berat dan zat warna, pengawet, anti spora 
dan yang terakhir dapat sebagai anti bakteri [5][6][7][8]. Tujuan penelitian ini yaitu melakukan ekstraksi kitin dari limbah cangkang rajungan melalui proses deproteinasi dan demineralisasi.

\section{Metodologi Penelitian}

Penelitian ini dilakukan di Laboratorium pengolahan limbah dan Laboratorium Nanoteknologi yang bertempat di gedung Loka Penelitian Teknologi Bersih (LPTB) Lembaga Ilmu Pengetahuan Indonesia (LIPI) pada tahun 2019.

\section{Ekstraksi Kitin}

Metode ekstraksi kitin berdasarkan metode [9] dengan uraian proses demineralisasi dahulu baru dilanjutkan deproteinasi. Pada penelitian ini proses ekstraksi dimodifikasi dengan deproteinasi dilakukan terlebih dahulu sebelum proses demineralisasi. Uraian metode yang digunakan sebagai berikut:

1. Limbah cangkang rajungan sebesar $\pm 2 \mathrm{~kg}$ berat kering (BK) cangkang rajungan. Cangkang dicuci dan dikeringkan. Selanjutnya cangkang rajungan dihaluskan menggunakan mortar hingga menjadi potongan-potongan kecil agar mempermudah ketika dihaluskan menggunakan blender. Potonganpotongan cangkang kemudian dimasukan kedalam blender hingga berbentuk seperti pasir/serbuk. Hasil blender kemudian dimasukan kedalam shaker batch dengan ukuran ayakan 200 mesh. Penelitian ini menggunakan ayakan ukuran 200 mesh dikarenakan 200 mesh sudah menghasilkan serbuk rajungan halus/ berbentuk tepung untuk mempermudah proses ekstraksi.

2. Tepung serbuk rajungan yang didapatkan sebesar 493,288 gr (BK). Dalam satu kali proses hanya menggunakan 200 gr tepung rajungan. Tahap deproteinasi disini yaitu dilakukan penambahan $\mathrm{NaOH}$ dalam konsentrasi 0,3 M dengan ketentuan 1:15 (b/v) selama 1 jam lama perendaman sambil dipanaskan pada suhu $80-85^{\circ} \mathrm{C}$ dengan diaduk terus menerus. Setelah 1 jam, dilakukan penyaringan untuk memisahkan tepung serbuk cangkang rajungan dengan larutan $\mathrm{NaOH}$. Tepung serbuk cangkang rajungan kemudian ditambahkan kembali menggunakan $\mathrm{NaOH}$ yang baru. Lakukan proses ini sebanyak 3 kali (3 kali pencucian secara bertahap). Tepung serbuk hasil deproteinasi disaring dan dicuci aquades hingga air pencucian memiliki $\mathrm{pH}$ netral.

3. Serbuk yang telah dicuci kemudian dilakukan tahap demineralisasi menggunakan penambahan larutan $\mathrm{HCl}$ dengan konsentrasi 0,55 $\mathrm{M}$ dalam ketentuan 1:10 (b/v) selama 1 jam lama perendaman pada kondisi suhu ruang sambil diaduk terus menerus. Setelah 1 jam, dilakukan penyaringan untuk memisahkan larutan $\mathrm{HCl}$ dengan cangkang rajungan. Tepung serbuk cangkang rajungan yang telah disaring tambahkan kembali menggunakan $\mathrm{HCl}$ yang baru. Lakukan proses ini sebanyak 5 kali (5 kali pencucian secara bertahap) [9]. Menurut [10] dilakukan pengulangan dalam pencucian diperkirakan jauh lebih baik dalam melarutkan kandungan mineral dibandingkan dengan proses pencucian tidak bertahap.

4. Serbuk hasil demineralisasi disaring dan dicuci menggunakan aquades hingga air pencucian memiliki pH netral. Hasil demineralisasi kemudian dikeringkan. Hasil ekstraksi kitin yang telah dikeringkan menggunakan oven dianalisis dengan metoda FTIR untuk analisa gugus fungsi dan menggunakan (SEM) untuk analisa morfologi.

\section{Hasil dan Pembahasan}

Proses ekstraksi kitin pada umumnya terdiri dari deproteinasi, demineralisasi dan dekolorisasi. Proses deproteinasi dalam ekstraksi kitin berperan sebagai penghilang/pemisah kandungan protein di dalam cangkang dengan kandungan kitin. Protein akan terlepas dan menjadi larut melalui proses deproteinasi dikarenakan penggunaan larutan $\mathrm{NaOH}$ dengan waktu yang lama dan dalam kondisi panas [11].

Protein yang telah terekstrak akan terbentuk Na-protein. Ujung rantai yang bermuatan negatif dalam protein akan terikat dengan ion $\mathrm{Na}^{+}$dari larutan $\mathrm{NaOH}$ sehingga protein akan mengendap. Menurut [12] reaksi yang terjadi pada tahap ini yaitu:

$$
\text { Protein }+\mathrm{NaOH} \longrightarrow \text { Na-proteinat }+\mathrm{H}_{2} \mathrm{O}
$$

Persamaan (1) juga menjelaskan ketika tahap deproteinasi kandungan protein diubah menjadi garam natrium proteinat yang dapat larut dalam air [13] sehingga $\mathrm{Na}^{+}$mengikat ujung rantai protein yang bermuatan tidak positif (negatif) [2]. 

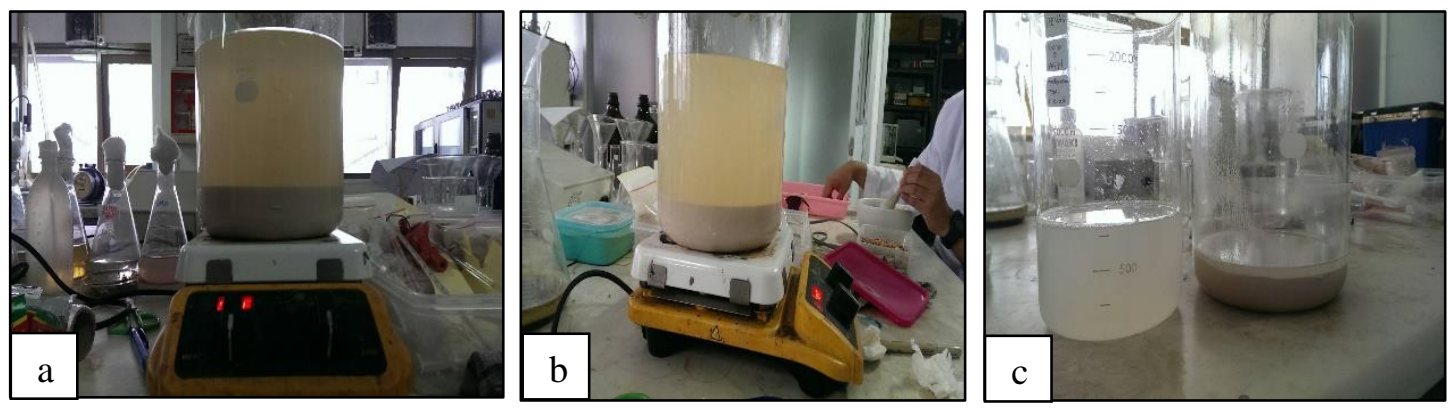

Gambar 1. (a) Deproteinasi tahap 1, (b) tahap 2 dan (c) Air pencucian $\mathrm{NaOH}$ ke 3 Sumber: Hasil penelitian, 2019

Hasil deproteinasi dicuci dengan aquades hingga air pencucian memiliki $\mathrm{pH}$ netral untuk membersihkan dari $\mathrm{NaOH}$ yang tersisa. Serbuk hasil proses deproteinasi yaitu 195 gr dari berat yang digunakan 200 gr. Dapat dikatakan bahwa protein yang hilang pada saat proses deproteinasi yaitu sebanyak 5 gr atau sebesar 2,5\%.

Setelah melalui proses deproteinasi tahapan ekstraksi dilanjutkan dengan proses demineralisasi. Proses demineralisasi berperan dalam memisahkan mineral yang masih terkandung dalam limbah cangkang dimana mineral ini terdiri dari $\mathrm{CaCO}_{3}$ dan $\mathrm{Ca}_{3}\left(\mathrm{PO}_{4}\right)_{2}$ dalam jumlah yang kecil. Kandungan ini dapat dipengaruhi oleh tempat hidupnya masing-masing [2].
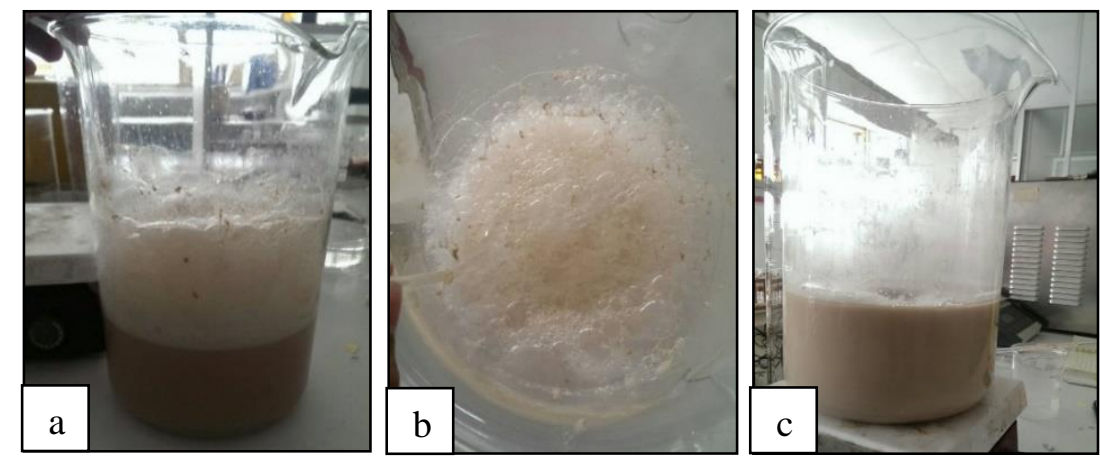

Gambar 2. (a) Terbentuknya gelembung, (b) Gelembung yang terbentuk, (c) Gelembung berkurang dalam pencucian terakhir

Sumber: Hasil penelitian, 2019

Larutan $\mathrm{HCl}$ secara perlahan direaksikan dengan serbuk rajungan untuk menghindari terjadinya luapan buih, dikarenakan larutan $\mathrm{HCl}$ yang direaksikan dengan limbah cangkang rajungan akan terbentuk gelembung (buih). Terbentuknya buih menandakan bahwa adanya gas karbondioksida dan uap air [12]. Pencampuran $\mathrm{HCl}$ juga menghasilkan fitrat berwarna keruh. Senyawa kalsium akan terjadi reaksi dengan larutan $\mathrm{HCl}$ didalam proses demineralisasi,dan membuat kandungan mineral dengan $\mathrm{HCl}$ yang larut di dalam air. Menurut [12] terjadi reaksi dari proses demineralisasi sebagai berikut:

$$
\begin{aligned}
& \mathrm{CaCO}_{3}(\mathrm{~s})+2 \mathrm{HCl}(\mathrm{aq}) \longrightarrow \mathrm{CaCl}_{2}(\mathrm{aq})+\mathrm{H}_{2} \mathrm{O}(\mathrm{l})+\mathrm{CO}_{2}(\mathrm{~g}) \\
& \mathrm{Ca}_{3}\left(\mathrm{PO}_{4}\right)_{2}(\mathrm{~s})+4 \mathrm{HCl}(\mathrm{aq}) \longrightarrow 2 \mathrm{CaCl}_{2}(\mathrm{aq})+\mathrm{Ca}\left(\mathrm{H}_{2} \mathrm{PO}_{4}\right)_{2}(\mathrm{aq})
\end{aligned}
$$

Persamaan (2) dan (3) menjelaskan bahwa ketika dilakukan penambahan $\mathrm{HCl}$ akan bereaksi dengan kandungan mineral didalam kitin seperti $\mathrm{CaCO}_{3}$ dan $\mathrm{Ca}_{3}\left(\mathrm{PO}_{4}\right)_{2}$ dikarenakan menurut [14] mineral yang terkandung di dalam cangkang rajungan diantaranya kalsium karbonat dan sedikit kasium pospat yang mana kandungan tersebut akan mudah hilang ketika ditambahkan $\mathrm{HCl}$. Terbentuknya buih pada proses ini dikarenakan adanya karbon dioksida $\left(\mathrm{O}_{2}\right)$ dan uap air yang terbentuk ketika $\mathrm{HCl}$ bereaksi dengan kandungan mineral.

Serbuk hasil demineralisasi dicuci dengan aquades hingga air pencucian memiliki $\mathrm{pH}$ netral. Asam amino bebas dapat berdisosiasi dengan asam atau berdifusinya asam dengan protein dapat menyebabkan kerusakan pemutusan suatu rantai di dalam proses pengeringan. Kerusakan pemutusan rantai dapat dihindari dengan proses pencucian menggunakan aquades [13]. Kitin yang diperoleh dari proses yang telah dilakukan yaitu sebesar 24,76 gr dari berat kering total serbuk rajungan 200 gr. Kitin 
yang didapat dianalisis karakteristik gugus fungsi menggunakan FTIR. Melalui Gambar $\mathbf{4}$ dan Gambar $\mathbf{5}$ menunjukkan proses pengujian dan hasil gugus fungsi kitin hasil ekstraksi melalui pengujian FTIR:

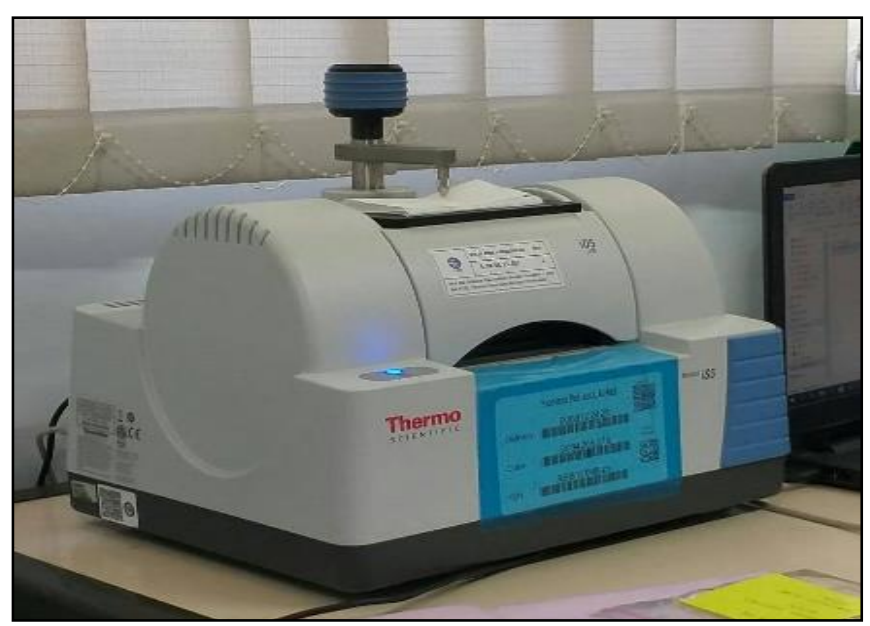

Gambar 3. Alat FTIR yang digunakan

Sumber: Dokumen pribadi, 2019

FTIR digunakan untuk menguji karakteristik kitin dimana hasil pengujian akan memperlihatkan gugus fungsi yang menunjukan ciri khas dari kitin. Vibrasi atom dalam suatu molekul menjadi suatu prinsip pengujian FTIR. Sampel uji akan dilewatkan gelombang elektromagnetik sehingga menghasilkan spectrum inframerah .Fraksi di dalam sampel dapat ditentukan berdasarkan masing-masing radiasi penyerapan energi yang dapat terlihat di dalam panjang gelombang tertentu [15][16].

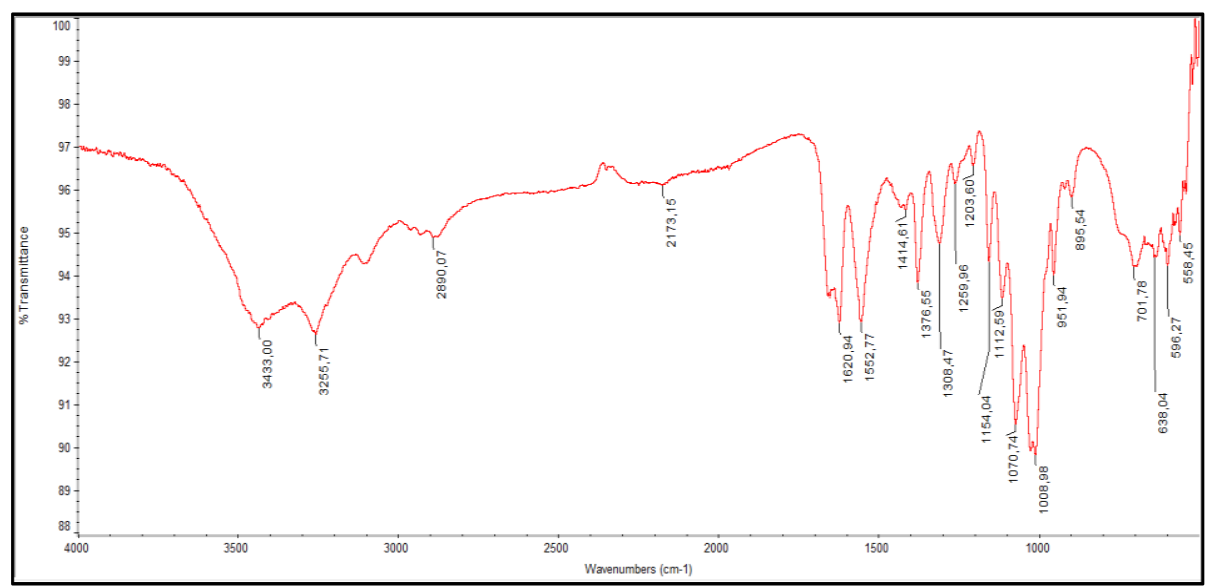

Gambar 4. Spektra FTIR kitin hasil ekstraksi

Sumber: Hasil penelitian, 2019

Senyawa kitin hasil ekstraksi Gambar 4 akan dibandingkan dengan hasil senyawa kitin standar Gambar $\mathbf{5}$ yang bertujuan untuk membuktikan apakah cangkang rajungan yang telah diekstraksi telah terbentuk menjadi kitin. 


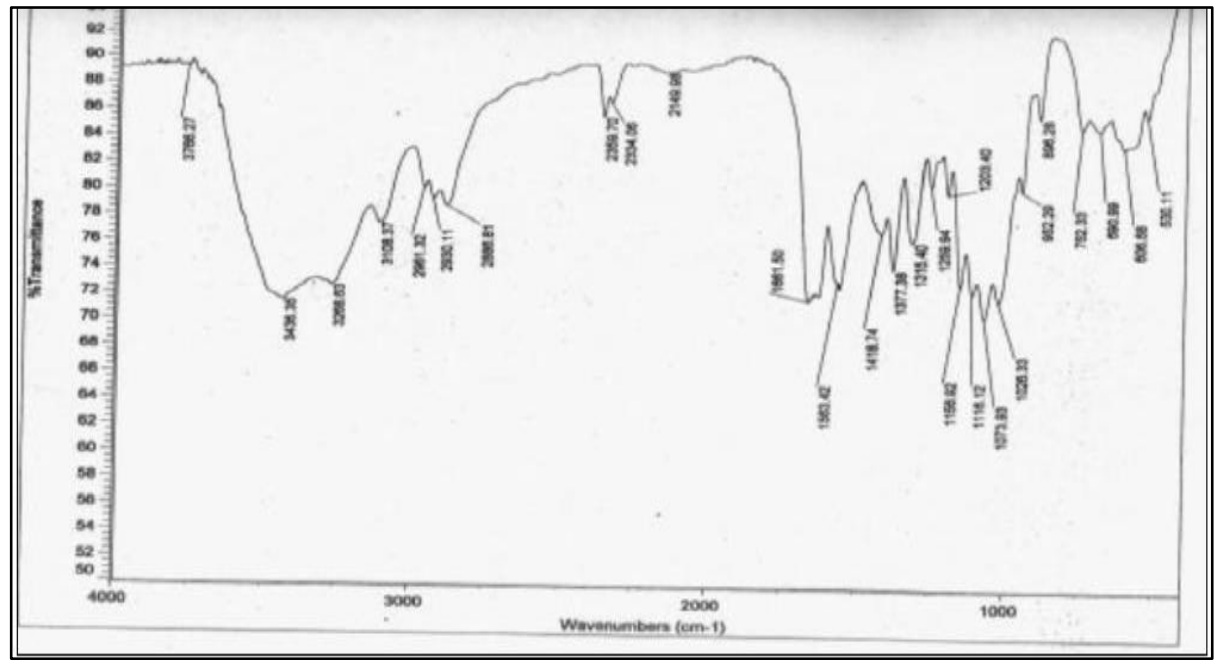

Gambar 5. Kitin Standar

Sumber: Dompeipen (2017)

Berikut hasil perbandingan hasil FTIR kitin standar menurut [17] dengan kitin hasil ekstraksi dapat dilihat melalui Tabel 1.

Tabel 1. Gugus fungsi kitin beserta bilangan gelombang

\begin{tabular}{cccc}
\hline \multirow{2}{*}{ No } & \multirow{2}{*}{ Gugus Fungsi } & \multicolumn{2}{c}{ Bilangan Gelombang $\left(\mathrm{cm}^{-1}\right)$} \\
\cline { 3 - 4 } & & Kitin Standar & Kitin Ekstraksi \\
\hline 1 & $-\mathrm{NH}$ & 3436 & 3433 \\
2 & $-\mathrm{OH}$ & 3268 & 3255 \\
3 & $-\mathrm{CH}$ & 2886 & 2890 \\
4 & $-\mathrm{NH}$ & 1661 & 1620 \\
5 & $-\mathrm{C}-\mathrm{N}$ & 1418 & 1414 \\
6 & $\mathrm{C}-\mathrm{O}$ & 1073 & 1070 \\
7 & $-\mathrm{NH}$ & 1026 & 1009 \\
8 & C-O-C & 896 & 805 \\
9 & $\beta-1,4-$ glikosidik & 752 & 701 \\
\hline
\end{tabular}

Sumber: Hasil penelitian, 2019

Berdasarkan Tabel 1 ketika dilakukan perbandingan spektrum FTIR kitin hasil ekstraksi dengan kitin standar spektrum yang dihasilkan menunjukkan bilangan gelombang yang hampir sama, dimana masing-masing spektrum menunjukkan ciri khas dari senyawa kitin. Hasil FTIR memperlihatkan spektrum ciri khas senyawa kitin seperti bilangan gelombang $3433 \mathrm{~cm}^{-1}$ untuk gugus $-\mathrm{OH}$, $-\mathrm{NH}$. Bilangan gelombang $3433 \mathrm{~cm}^{-1}$ memiliki serapan yang cukup lebar, hal ini dikarenakan gugus -NH dan $\mathrm{OH}$ yang menyebabkan tumpang tindih antar serapan [18] dan bilangan gelombang $701 \mathrm{~cm}^{-1}$ untuk gugus $\beta$-1,4-glikosidik [19]. Serapan yang lebih kecil akan dihasilkan dari gugus amina dibandingkan gugus yang melebar dari hidroksida. Amina menghasilkan serapan yang kecil dikarenakan amina yang memiliki ikatan hidrogen kurang kuat serta gugus $\mathrm{N}-\mathrm{H}$ memiliki ikatan yang kurang polar dalam sebagian gugusnya [20]. Hal ini memberikan informasi bahwa melalui proses deproteinasi dan demineralisasi yang dilakukan telah berhasil mengubah cangkang rajungan yang digunakan menjadi kitin.

Selain dilakukan uji gugus fungsi melalui FTIR, kitin yang dihasilkan dilakukan pengujian menggunakan SEM untuk diketahui karakteristik morfologi kitin. Hasil pengujian SEM kitin dapat dilihat melalui Gambar 6. 

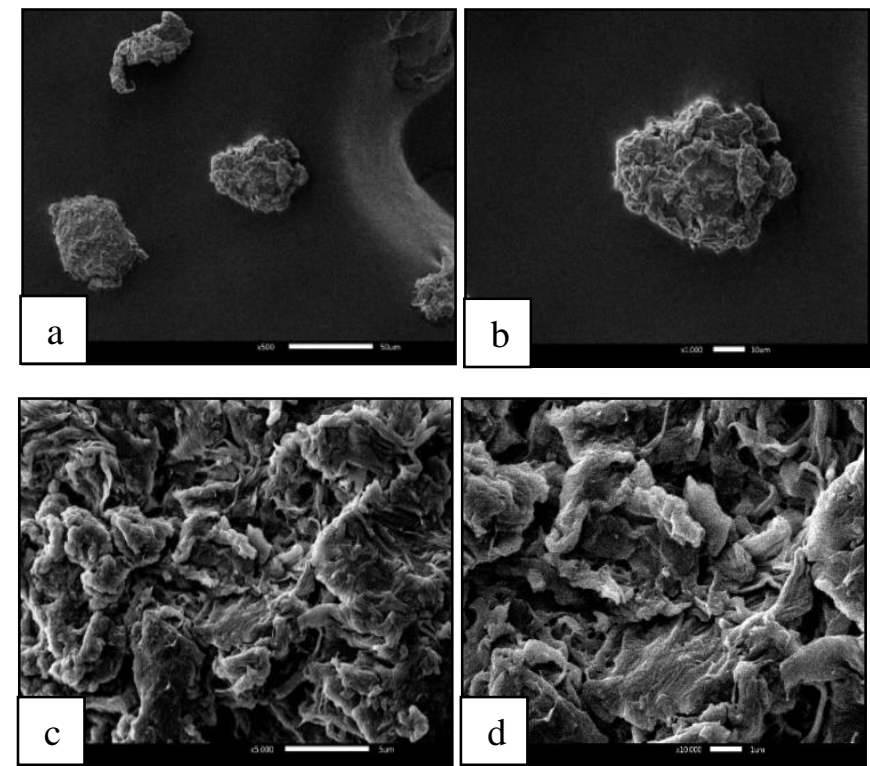

Gambar 6. Perbesaran (a) 500x, (b) 1.000x, (c) 5.000x, dan (d) 10.000x Sumber: Hasil penelitian, 2019

Morfologi kitin yang dihasilkan kemudian dibandingkan dengan kitin standar. Perbandingan morfologi kitin diperlihatkan melalui Gambar 7.
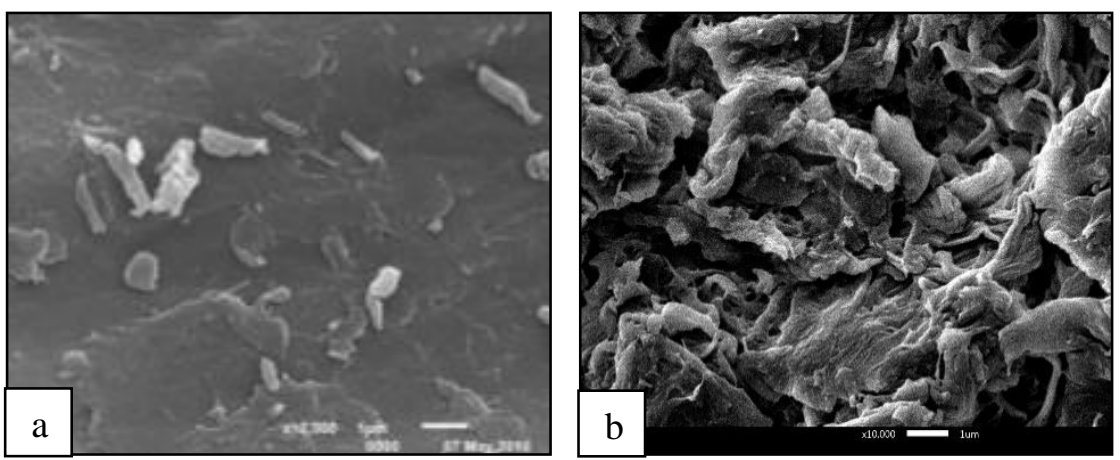

Gambar 7. (a) Kitin Standar 10.000x (Sumber: Rukman, 2019), (b) Kitin hasil ekstraksi 10.000x Sumber: Hasil penelitian, 2019

Kitin memiliki bentuk morfologi padatan amorf berwarna putih dengan struktur kristal. Amorf merupakan jenis padatan yang susunan atom atau partikelnya tersusun secara acak dan tidak teratur [21]. Hasil SEM yang dibandingkan yaitu digunakan pada perbesaran $10.000 \mathrm{x}$ yang berfungsi agar morfologi dapat terlihat jelas ketika dilakukan perbandingan. Kitin standar yang digunakan yaitu bersumber dari kulit udang [22]. Ketika dibandingkan kitin hasil ekstraksi lebih terlihat bentuk nya dengan terlihat kasar dan seperti bergerombol, sedangkan kitin standar lebih terlihat halus dan lebih terlihat berjarak. Hal ini menunjukan morfologi kitin tidak selalu sama dan dapat berbeda tergantung dari asal hewan crustacea yang digunakan. Karena lingkungan tempat hewan crustacea tersebut hidup dapat mempengaruhi morfologi kitin tersebut [22].

\section{Kesimpulan}

Melalui proses modifikasi ekstraksi kitin dengan didahului proses deproteinasi dan demineralisasi limbah cangkang rajungan telah berhasil diekstraksi menjadi kitin. Kitin yang diperoleh dari proses yang telah dilakukan yaitu sebesar 24,76 gr (bk) dari total serbuk rajungan 200 gr (bk). Kitin memiliki bermanfaat dalam kehidupan sehari-hari misalnya sebagai adsorben limbah logam berat dan zat warna, pengawet, anti jamur, kosmetik, farmasi, flokulan, anti kanker, dan anti bakteri.

\section{Daftar Pustaka}

[1] Direktorat Jenderal Pengelolaan Ruang Laut. Konservasi Perairan Sebagai Upaya menjaga Potensi Kelautan dan Perikanan Indonesia. Kkp.Go.Id. https://kkp.go.id/djprl/artikel/21045-konservasiperairan-sebagai-upaya-menjaga-potensi-kelautan-dan-perikanan-indonesia\#: :text=Dari total luas 
wilayah tersebut,dan perikanan yang sangat besar. 2020

[2] Emma Rochima. Karakterisasi Kitin Dan Kitosan Asal Limbah Rajungan Cirebon Jawa Barat. Buletin Teknologi Hasil Perikanan, x. 2017

[3] Amalia, A. N. Pemanfaatan Cangkang Rajungan Sebagai Koagulan Untuk Penjernih Air. 2018.

[4] Ornum, V. Shrimp Waste-Must it be Wasted. INFOFISH International, 48-52. 1992

[5] Harish Prashanth, K. V., \& Tharanathan, R. N. Chitin/chitosan: modifications and their unlimited application potential-an overview. Trends in Food Science and Technology, 18(3), 117-131. https://doi.org/10.1016/j.tifs.2006.10.022. 2007

[6] Stephen, A. M., Phillips, G. O., \& Williams, P. A. Food Polysaccharides and Their Applications: Second Edition. In Food Polysaccharides and Their Applications: Second Edition. 2016.

[7] Lee, S., Cho, J. S., \& Cho, G. Antimicrobial and Blood Repellent Finishes for Cotton and Nonwoven Fabrics Based on Chitosan and Fluoropolymers. Textile Research Journal, 69(2), 104-112. https://doi.org/10.1177/004051759906900205. 1999

[8] N Liu, X.G Chen, H.J Park, C.G Liu, X.H Meng, L. . Y. Effect of $M W$ and concentration of chitosan on antibacterial activity of Escherichia coli. Carbohydrate Polymers. 64(1), 60-65. 2006

[9] Rhazi, M., Desbrières, J., Tolaimate, A., Alagui, A., \& Vottero, P. Investigation of different natural sources of chitin: Influence of the source and deacetylation process on the physicochemical characteristics of chitosan. Polymer International, 49(4), 337-344. 2000

[10] Tolaimate, A., Desbrieres, J., Rhazi, M., \& Alagui, A. Contribution to the preparation of chitins and chitosans with controlled physico-chemical properties. Polymer, 44(26), 7939-7952. https://doi.org/10.1016/j.polymer.2003.10.025. 2003

[11] Suhardi. Khitin dan Khitosan. Pusat Antar Universitas Pangan Dan Gizi.Universitas Gajah Mada. 1993

[12] Pitriani, P. Sintesin Dan Aplikasi Kitosan Dari Cangkang Rajungan (Portunus). 1-99. 2010

[13] Purwatiningsih, S, Wukisari, T, Sjahriza, A \& Wahyono, D. Kitosan Sumber Biomaterial Masa Depan. IPB Press. 2009

[14] Ruswanti, I., Si, M., Lusiana, R. A., \& Si, M. Dan Aplikasinya Sebagai Adsorben Ion Mangan ( II ) dan Besi ( II ) ( Solid Chitosan Membrane From Crabs's Shell ( Portunus pelagicus) and Application as Adsorbent of Ion Manganese ( II ) and Iron ( II )) Abstrak Membran kitosan padat dari cangkang raju. 4(Ii). 2008

[15] Kumirska, J., Czerwicka, M., Kaczyński, Z., Bychowska, A., Brzozowski, K., Thöming, J., \& Stepnowski, P. Application of spectroscopic methods for structural analysis of chitin and chitosan. Marine Drugs, 8(5), 1567-1636. https://doi.org/10.3390/md8051567. 2010

[16] Stuart, B. Infrared Spectroscopy: Fundamentals and Application (Analytical Techniques in the Science (AnTs) *). 2004

[17] Dompeipen, E. J. Isolasi Dan Identifikasi Kitin Dan Kitosan Dari Kulit Udang Windu ( Penaeus monodon ) Dengan Spektroskopi Inframerah. Majalah BIAM, 13(1), 31-41. 2017

[18] Purnawan, C, Aprilita NH, Kartini I., \& S. E. Kajian Parameter Deasetilasi Kitin dari Cangkang Udang Berdasarkan Karakter Spektra Infra Merah (IR). Prosiding Seminar Nasional Kimia Dan Pendidikan Kimia, 499-513. 2009

[19] Das, S., Roy, D., \& Sen, R. Utilization of Chitinaceous Wastes for the Production of Chitinase. In Advances in Food and Nutrition Research (1st ed., Vol. 78). Elsevier Inc. https://doi.org/10.1016/bs.afnr.2016.04.001. 2016

[20] Djaenudin, Budianto, E., Saepudin, E., \& Nasir, M. Ekstraksi Kitosan Dari Cangkang Rajungan Pada Lama Dan Pengulangan Perendaman Yang Berbeda. Jurnal Teknologi Dan Kelautan, 10(1), 49-59. 2019

[21] Surya, Y. Fisika Modern. Penerbit Kandel. 2009

[22] Hertadi, R. Extraction and Characterization of Chitin and Chitosan from Black Soldier Fly (Hermetia illucens). Jurnal Ilmiah Farmako Bahari. 2019 